\title{
PERLINDUNGAN HAK KONSTITUSIONAL OLEH MAHKAMAH KONSTITUSI: PEMBATALAN LARANGAN PERNIKAHAN PEGAWAI SATU ATAP
}

\author{
Septina Lia Triastuti \\ Magister Ilmu Hukum, Fakultas Hukum, Universitas Diponegoro \\ Jalan Imam Bardjo No.1, Semarang \\ septina.lia.t@gmail.com
}

\begin{abstract}
The Constitutional Court (MK) granted the protection of constitutional right of coworkers in the same enterprise. Before the Constitutional Court decision Number 13/PUU-XV/2017 decided, workers claimed they could lose their jobs due to marriage to coworkers and discrimination of constitutional right as accommodated by Article 27 and 28 of the 1945 constitution. After the Article 153 paragraph (1) letter f of Law Number 13/2003 has been abrogated, it is important to analyze the impacts of the decision toward the Labor Law in Indonesia also the law consequenses for company's internal regulation. After the Constitutional Court publishes the decision through the Official Gazzette, companies should synchronize their internal rules to avert the lawsuit from the coworkers/related parties.
\end{abstract}

Keywords: Constitutional Court; Labor Law; Marriage between Coworkers

\begin{abstract}
Abstrak
Mahkamah Konstitusi mengabulkan perlindungan hak konstitusional pekerja yang melaksanakan pernikahan sesama pekerja dalam satu atap perusahaan. Sebelum terbit putusan Putusan Nomor 13/PUU-XV/2017, banyak pekerja kehilangan pekerjaan, merasa dirugikan, dan diskriminasi hak konstitunionalnya, sebagaimana diakomodir dalam Pasal 27 dan Pasal 28 UUD 1945. Setelah Pasal 153 ayat (1) UU Ketenagakerjaan dibatalkan oleh Mahkamah Konstitusi, patut dianalisis bagaimana dampak putusan tersebut bagi undang-undang ketenagakerjaan di Indonesia serta konsekuensi hukumnya terhadap peraturan internal perusahaan. Setelah putusan Mahkamah Konstitusi dimuat dalam Berita Negara Republik Indonesia, idealnya perusahaan-perusahaan di Indonesia harus melakukan penyesuaian terhadap ketentuan internal perusahaannya untuk mencegah timbulnya gugatan dari pihak-pihak terkait.
\end{abstract}

Kata kunci: Mahkamah Konstitusi; UU Ketenagakerjaan; Pernikahan Pegawai Satu Atap Perusahaan

\section{A. Pendahuluan}

Problematika ketenagakerjaan sepanjang masa tidak pernah selesai, dari masalah perlindungan, pengupahan, kesejahteraan, perselisihan hubungan industrial, pembinaan, dan pengawasan ketenagakerjaan (Sutedi, 2009). Penyebabnya pun beragam, baik dari kompleksitas dimensi ekonomis, sosialkesejahteraan, sosial politik, dan sebagainya. 
Dari segi kesejahteraan, sebagaimana diakomodir dalam Pasal 1 angka 31 tentang ketentuan umum UU Nomor 13 Tahun 2003 tentang Ketenagakerjaan (selanjutnya disingkat UU Ketenagakerjaan), kesejahteraan pekerja/buruh adalah suatu pemenuhan kebutuhan dan/atau keperluan yang bersifat jasmaniah dan rohaniah, baik di dalam maupun di luar hubungan kerja, yang secara langsung atau tidak langsung dapat mempertinggi produktivitas kerja dalam ligkungan kerja yang aman dan sehat (Kansil, 2004). Dengan demikian, kesejahteraan bagi pekerja adalah bermakna luas, tidak semata-mata soal upah dan jasmaniah.

Salah satu permasalahan kesejahteraan dalam dunia ketenagakerjaan yang barubaru ini kembali timbul ke permukaan publik adalah mengenai para pekerja yang merasa dirugikan hak konsttitusionalnya dengan mengajukan permohonan pengujian UU Ketenagakerjaan kepada Mahkamah Konstitusi. Sebagaimana dijelaskan dalam Ringkasan Permohonan Perkara Nomor 13/PUU-XV/2017 mengenai Larangan Melakukan Perkawinan dengan Sesama Pegawai dalam Satu Perusahaan, diketahui bahwa para pemohon adalah delegasi dari beberapa pegawai, mantan pegawai, dan Dewan Serikat Pegawai PT PLN (Persero). Di dalam permohonan pengujian UU Ketenagakerjaan, Pasal 153 ayat (1) menjadi alasan/pokok perkara a quo. Kepada
Mahkamah Konstitusi, para pemohon menyampaikan bahwa di dalam peraturan perusahaan tempat para pemohon bekerja, terdapat aturan yang membatasi hak untuk menikah antara sesama pegawai dalam satu perusahaan yang sama. Pada perusahaan lain aturan ini biasanya diatur dalam suatu perjanjian kerja bersama (PKB) yang dibuat oleh pengusaha/direksi dan para pekerja/pegawai maupun dalam peraturan perusahaan yang dibuat oleh pihak pengusaha.

Aturan yang menyatakan bahwa apabila antara pekerja menikah dalam satu perusahaan, maka salah satu pekerja diantara mereka wajib mengundurkan diri dan akan dilakukan pemutusan hubungan kerja, yang tercantum dalam PKB maupun aturan perusahaan, tercantum dalam Pasal 153 ayat (1) huruf f UU Ketenagakerjaan yang berbunyi: pekerja/buruh mempunyai pertalian darah dan/atau ikatan perkawinan dengan pekerja /buruh lainnya di dalam satu perusahaan, kecuali telah diatur dalam perjanjian kerja, peraturan perusahaan, atau perjanjian kerja bersama. Dengan demikian, selama aturan larangan menikah tersebut masih ada dalam PKB, maka pekerja wajib tunduk pada aturan tersebut.

Larangan melaksanakan pernikahan tersebut dinilai sangat merugikan pemohon. Dengan tunduknya pekerja pada ketentuan perusahaan maupun PKB yang berdasarkan kepada UU Ketenagakerjaan, khususnya 
Pasal 153 ayat (1) tersebut menyebabkan hilangnya hak konstitusi pemohon dengan hilangnya jaminan kerja dan penghidupan yang layak. Sedangkan jaminan kerja dan penghidupan yang layak merupakan amanat dari UUD Negara Republik Indonesia Tahun 1945 yang diatur pada Pasal 28. Sejalan dengan hal tersebut, menurut Wurianalya Maria Novenanty, bahwa dalam Pasal 28B ayat 1 UUD 1945, sebagaimana dituangkan kembali dalam Undang-Undang HAM Pasal 10 mengenai hak atas kesejahteraan, termasuk diantaranya hak atas pekerjaan yang dinyatakan dalam pasal 38 ayat 1 Undang-Undang HAM: "Setiap warga negara, sesuai dengan bakat, kecakapan, dan kemampuan berhak atas pekerjaan yang layak." Kemudian dalam ayat 2 diatur bahwa setiap orang berhak dengan bebas memilih pekerjaan yang disukainya dan berhak pula atas syarat-syarat ketenagakerjaan yang adil. Hal ini pun didukung oleh Pasal 6 ayat 1 International Covenant On Economic, Social, and Cultural Rights (Kovenan Internasional Tentang Hak-Hak Ekonomi, Sosial, dan Budaya) yang telah diratifikasi oleh Undang-Undang Nomor 11 Tahun 2005 (untuk selanjutnya disebut sebagai "ICESCR"). Apabila pasal-pasal tersebut dikaitkan dengan aturan dalam suatu perusahaan yang mengharuskan salah satu dari pasangan pekerja yang telah menikah untuk keluar, bahkan dapat dilakukan 376
Pemutusan Hubungan Kerja terhadap pekerja tersebut, maka ada pelanggaran terhadap Pasal 38 Ayat 2 Undang-Undang HAM dan Pasal 6 Ayat 2 ICESCR, di mana kedua pasal tersebut pada intinya menyatakan bahwa setiap warga negara berhak dengan bebas memilih pekerjaan yang disukainya. Kebebasan memilih tersebut dibatasi atau bahkan dilanggar oleh suatu perusahaan yang menerapkan aturan wajib untuk mengundurkan diri atau bersedia di-PHK apabila menikah dengan sesama pekerja (Novenanty, 2016).

Setelah perkara diterima Kepaniteraan Mahkamah Konstitusi tertanggal 2 Februari 2017 dengan nomor perkara 13/PUUXV/2017, pada tanggal Pada tanggal 14 Desember 2017, Mahkamah Konstitusi menerbitkan putusan yang memberikan dampak luas bagi dunia ketenagakerjaan di Indonesia, khususnya dalam hal personaliasumber daya manusia. Putusan Mahkamah Konstitusi Nomor 13/P/PUU-XV/2017 tersebut, pada amar putusannya mengadili:

1. Mengabulkan permohonan para pemohon untuk seluruhnya;

2. Menyatakan frasa "kecuali telah diatur dalam Pasal 153 ayat (1) huruf $f$ Undang-Undang Nomor 13 Tahun 2013 Tentang Ketenagakerjaan bertentangan dengan Undang-Undang Dasar Negara Republik Indonesia Tahun 1945 dan tidak mempunyai kekuatan hukum mengikat". 
3. Memerintahkan pemuatan putusan ini dalam Berita Negara Republik Indonesia sebagaimana mestinya.

Berdasarkan kondisi tersebut, pasca terbitnya putusan Mahkamah Konstitusi Nomor 13/P/PUU-XV/2017 tersebut, perlu dilakukan suatu analisis/pembahasan yang penulis batasi ke dalam permasalahan sebagai berikut: Pertama, bagaimana akibat hukum putusan Mahkamah Konstitusi pada perkara a quo bagi UU Ketenagakerjaan di Indonesia? Kedua, bagaimana implikasi yuridis Putusan Mahkamah Konstusi pada perkara a quo terhadap suatu Perusahaan yang melarang pernikahan satu atap?

\section{B. Pembahasan}

\section{Kekuatan Hukum Putusan}

Mahkamah Konstitusi

Sebagaimana dikutip dari Abdul Rasyid Thalib, bahwa salah satu substansi di dalam perubahan ketiga UUD 1945 yang disahkan dalam sidang tahunan MPR tahun 2001 adalah diperintahkannya untuk membentuk organ (komponen) konstitusi yang dinamakan Mahkamah Konstitusi, yang kewenangan dan kewajibannya diatur dalam Pasal 7A, 7B, dan Pasal 24C UUD 45 (Thalib, 2006). Mahkamah Konstitusi berwenang:

a. Menguji undang-undang terhadap UUD;

b. Memutus sengketa kewenangan lembaga negara yang kewenangannya diberikan oleh UUD; c. Memutus pembubaran partai politik; dan

d. Memutus perselisihan tentang hasil pemilihan umum.

Kewibawaan suatu putusan yang dikeluarkan institusi peradilan terletak pada kekuatan mengikatnya. Putusan Mahkamah Konstitusi merupakan upaya yang pertama (the first resort) sekaligus upaya terakhir (the last resort) bagi para pencari keadilan. Artikulasi putusan final berarti tidak ada upaya hukum lebih lanjut yang dapat ditempuh terhadap putusan, sehingga menimbulkan konsekuensi bahwa putusan tersebut secara langsung mempunyai kekuatan hukum tetap dan memperoleh kekuatan hukum mengikat untuk dilaksanakan. Putusan memperoleh kekuatan final dan mengikat sejak diucapkan di dalam pleno yang terbuka untuk umum. Putusan final Mahkamah Konstitusi dimaksudkan agar dapat menyelesaikan persoalan dan memberikan kepastian hukum secara cepat sesuai dengan prinsip peradilan cepat dan sederhana mengingat perkara yang diajukan kepada Mahkamah Konstitusi merupakan perkara yang berkaitan dengan ketatanegaraan, sehingga membutuhkan kepastian hukum dan terikat dengan limitasi waktu agar tidak mengganggu keberlangsungan agenda ketatanegaraan. Jika tidak, kewibawaan peradilan konstitusional yang harus dipertaruhkan (Maulidi, 2017). Pada aspek yang lebih luas, karakteristik putusan 
Mahkamah Konstitusi merupakan putusan yang tidak hanya mengikat para pihak (inter parties) tetapi juga harus ditaati oleh siapapun (erga omnes). Asas erga omes tercermin dari ketentuan yang menyatakan bawa putusan MK langsung dapat dilaksanakan dengan tidak memerlukan lagi keputusan pejabat yang berwenang kecuali peraturan perundang-undangan mengatur lain (Ratnaningsih, 2017).

Asas putusan MK berkekuatan hukum tetap dan bersifat final sebagaimana diakomodir dalam Pasal 10 ayat (1) UU Nomor 24 Tahun 2003 sebagaimana telah diubah dengan Undang-Undang Nomor 8 Tahun 2011 Tentang Mahkamah Konstitusi, yang mengatur bahwa: "Mahkamah Konstitusiberwenang mengadili pada tingkat pertama dan terakhir yang putusannya bersifat final untuk: a. menguji undang-undang terhadap Undang-Undang Dasar Negara Republik Indonesia Tahun $1945^{\prime \prime}$.

Berdasarkan kewenangannya untuk menguji konstitusionalitas UU Nomor 24 Tahun 2003, Mahkamah Konstitusi melalui putusannya dapat menyatakan bahwa materi rumusan dari suatu undang-undang tidak mempunyai kekuatan hukum karena bertentangan dengan UUD. Begitupun terhadap suatu undang-undang, Mahkamah Konstitusi dapat membatalkan keberlakuannya karena tidak sesuai dan tidak berdasarkan UUD (Daulay, 2006).
2. Akibat Hukum Putusan Mahkamah Konstitusi terhadap UU

\section{Ketenagakerjaan}

Pertimbangan disusunnya UU Nomor 13 Tahun 2003 tentang Ketenagakerjaan adalah untuk mendukung pembangunan nasional dalam rangka pembangunan manusia Indonesia seutuhnya untuk mewujudkan masyarakat yang sejahtera, adil, makmur, yang merata baik materiil maupun spiritual berdasarkan Pancasila dan Undang-Undang Dasar Negara Republik Indonesia Tahun 1945. Pembangunan ketenagakerjaan sebagai bagian integral dari pembangunan nasional berdasarkan Pancasila dan UUD 1945, dilaksanakan dalam rangka pembangunan manusia Indonesia seutuhnya meningkatkan harkat, martabat, dan harga diri tenaga kerja serta mewujudkan masyarakat sejahtera, adil, makmur, dan merata, baik materiil maupun spiritual. Selain dengan meningkatkan pembangunan ketenagakerjaan, diperlukan pula peningkatan perlindungan tenaga kerja dan keluarganya sesuai dengan harkat dan martabat kemanusiaan. Perlindungan terhadap tenaga kerja dimaksudkan untuk menjamin hak-hak dasar pekerja/buruh dan menjamin kesamaan kesempatan serta perlakuan tanpa diskriminasi atas dasar apapun untuk mewujudkan kesejahteraan.

Apabila dicermati dari dasar pertimbangan penyusunannya, amanat yang diemban oleh UU Ketenagakerjaan cukup 
berat untuk dilaksanakan di dalam dunia ketenagakerjaan, terlebih ketika timbul keraguan atas kelayakan undang undang tersebut. Sebagaimana dalam pokok perkara yang diajukan para pemohon dalam Perkara Nomor 13/PUU-XV/2017. Pada perkara $a$ quo, para pemohon mengajukan permohonan uji materiil UU Ketenagakerjaan dinilai bertentangan dengan UUD Negara Republik Indonesia Tahun 1945 dan hak kosntitusional warga negara. Pada UUD Negara Republik Indonesia Tahun 1945 mengatur:

a. Pasal 28B ayat (1) yang berbunyi:

"Setiap orang berhak membentuk keluarga dan melanjutkan keturunan melalui perkawinan yang sah.,

Hal ini telah ditegaskan pula dalam Pasal 10 ayat (1) UU No. 39 Tahun 1999 :

1. setiap orang berhak membentuk suatu keluarga dan melanjutkan keturunan melalui perkawinan yang sah.

2. Perkawinan yang sah hanya dapat berlangsung atas kehendak bebas calon suami dan calon istri yang bersangkutan, sesuai dengan ketentuan peraturan perundangundangan.

b. Pasal 28D ayat (2) yang berbunyi:

"Setiap orang berhak untuk bekerja serta mendapat imbalan dan perlakuan yang adil dan layak dalam hubungan kerja."
Hal ini telah ditegaskan pula dalam Pasal 38 ayat (1) dan ayat (2) UU No. 39 Tahun 1999 yang berbunyi :

(1) Setiap orang berhak, sesuai dengan bakat, kecakapan, dan kemampuan, berhak atas pekerjaan yang layak.

(2) Setiap orang berhak dengan bebas memilih pekerjaan yang disukainya dan berhak pula atas syarat-syarat ketenagakerjaan.”

Sejalan dengan UUD 1945, Pasal 23 ayat (1) Deklarasi HAM PBB juga menegaskan bahwa: "setiap orang berhak atas pekerjaan, berhak dengan bebas memilih pekerjaan, berhak atas syaratsyarat perburuhan yang adil dan menguntungkanserta berhak atas perlindungan dari pengangguran”.

Ketentuan-ketentuan tersebut juga sejalan dengan ketentuan yang termuat dalam Pasal 6 ayat (1) International Covenant on Economic, Social, Cultural Rights (Kovenan Internasional tentang Hak Hak Ekonomi, Sosial dan Budaya) menyatakan : "negara negara Pihak pada Kovenan ini mengakui hak atas pekerjaan, termasuk hak atas setiap orang atas kesempatan untuk mencari nafkah melalui pekerjaan yang dipilih atau diterimanya sendiri secara bebas, dan akan mengambil langkah-langkah yang tepat guna melindungi hak tersebut", 
Setelah dicermati, apabila dibandingkan antara norma-norma yang dikandung dalam UUD Tahun 1945 maupun deklarasi HAM PBB berikut Kovenan Internasional tentang Hak Hak Ekonomi, Sosial dan Budaya, ketentuan Pasal 153 ayat (1) UU Ketenagakerjaan bertentangan dengan hak konstitusional tiap-tiap pekerja sebagai warga negara. Adanya ketentuan Pasal 153 ayat (1) huruf f UU No. 13 Tahun 2003 membawa konsekuensi bahwa Pemberi Kerja akan melakukan pelarangan adanya perkawinan sesama Pekerja dalam satu Perusahaan.

Apabila dilihat dari sinkronisasi ketentuan undang-undang ketenagakerjaan dengan UUD 1945, sudah seharusnya UU Ketenagakerjaan menyesuaikan dan tidak bertentangan dengan ketentuan yang lebih tinggi. Peraturan perundang-undangan mempunyai suatu hirarki seperti yang dikemukakan oleh Hans Kelsen dalam teori jenjang norma hukum (stufentheori), yang mengatakan norma hukum itu berjenjang dan berlapis dalam suatu hirarki (Samosir, 2015). Selain itu berlaku pula asas Lex superior derogate legi inferiori: perundangundangan bertingkat lebih tinggi mengesampingkan perundang-undangan tingkat lebih rendah, kecuali bila substansi perundang-undangan yang lebih tinggi mengatur hal-hal yang oleh Undang-Undang ditetapkan menjadi wewenang perundangundangan yang lebih rendah.
Sebagaimana diakomodir dalam tata urutan hierarki perundangan (Pasal 7 ayat 1 UU No.12 tahun 2011) yang secara berjenjang urutannya adalah:
$i$ UUD
ii. Ketetapan MPR
iii. UU
iv. Peraturan Pemerintah
v. Peraturan Presiden
vi. Perda Provinsi

Kekuatan mengikat putusan Mahkamah Konstitusi berbeda dengan putusan pengadilan biasa, yang tidak hanya meliputi pihak-pihak berpekara (yaitu Pemohon, Pemerintah, DPR/DPD) ataupun pihak terkait yang diizinkan memasuki perkara, tetapi putusan tersebut juga mengikat bagi semua orang, lembaga negara dan badan hukum dalam wilayah Republik Indonesia. Ia berlaku sebagai hukum sebagaimana hukum diciptakan pembuat undang-undang (Prang, 2011). Guru Besar Hukum Universitas Andalas, Prof. Saldi Isra juga menerangkan bahwa, apabila MK melalui putusan pengujian undang-undang terhadap UUD menyatakan: materi muatan ayat, pasal, dan/atau bagian dari suatu UU bertentangan dengan UUD 1945 dan tidak mempunyai kekuatan hukum mengikat, maka sejak saat itu, putusan tersebut bersifat final. Sehingga norma yang telah dinyatakan bertentangan dengan UUD 1945 tidak lagi dapat dijadikan dasar hukum untuk 
mengambil tindakan atau putusan(Isra, 2015).

\section{Penyesuaian Aturan Perusahaan}

\section{Pasca Terbitnya Putusan}

\section{Mahkamah Konstitusi}

Putusan Mahkamah Konstitusi sejak diucapkan di hadapan siding yang terbuka untuk umum dapat mempunyai 3 (tiga) kekuatan, yaitu kekuatan mengikat, kekuatan pembuktian, dan kekuatan eskekutorial (Kapitan, 2015). Pada perkara $a$ quo, para pemohon dalam permohonannya kepada Mahkamah Konstitusi mengemukakan bahwa hak konstitusionalnya telah dirugikan oleh berlakunya Pasal 153 ayat (1) huruf f UU Nomor 13 Tahun 2003 berupa jaminan kerja dan penghidupan yang layak karena ketentuan tersebut dapat menyebabkan terjadinya pemutusan kerja. Dalam hal Perusahaan membuat Peraturan Perusahaan sesuai dengan Pasal 153 ayat (1) huruf f UU No. 13 Tahun 2003, maka Perusahaan akan menghilangkan jaminan kerja Para Pekerja yang akan melakukan Perkawinan sesama Pekerja dalam satu perusahaan dan juga menghilangkan hak atas penghidupan yang layak serta mendapat imbalan dan perlakuan yang adil dalam hubungan keja yang dijamin oleh Pasal 28D ayat (1) UUD 1945 yang berbunyi: "Setiap orang berhak atas pengakuan, jaminan, perlindungan, dan kepastian hukum yang adil serta perlakuan yang sama dihadapan hukum."
Sudah menjadi kewajiban bagi setiap perusahaan untuk berpedoman pada Undang-Undang Ketenagakerjaan. Di dalam undang-undang ketenagakerjaan, diatur bahwa perusahaan yang mempekerjakan sekurang-kurangnya 10 (sepuluh) orang, pengusaha wajib membuat peraturan perusahaan kecuali perusahaan telah mempunyai perjanjian kerja bersama (Pasal 108 Undang-Undang Ketenagakerjaan). Persamaan peraturan perusahaan dengan perjanjian kerja bersama adalah sama-sama memuat tentang syarat-syarat kerja, hak dan kewajiban para pihak serta tata tertib perusahaan. Sedangkan perbedaannya (Rusli, 2004):

1. Peraturan kerja bersama dibuat oleh serikat pekerja dengan pengusaha. Sedangkan peraturan perusahaan dibuat oleh pengusaha.

2. Peraturan perusahaan memerlukan pengesahan dari Menteri Tenaga Kerja atau pejabat yang ditunjuk, sedangkan perjanjian kerja bersama tidak memerlukan pengesahan tersebut.

3. Perjanjian kerja bersama dibuat antara pengusaha dengan serikat pekerja, peraturan perusahaan dibuat oleh perusahaan.

4. Peraturan perusahaan dapat digantikan dengan perjanjian kerja bersama bila serikat pekerja menghendaki perundningan pembuatan perjanjian kerja bersama. Sedangkan perjanian 
kerja bersama tidak boleh digantikan dengan peraturan perusahaan selama masih ada serikat pekerjanya.

Pada perkara $a$ quo, meskipun pada saat perumusan perjanjian kerja bersama, antara pengusaha dengan pekerja melaksanakan kesepakatan pembuatan perjanjian, dalam hal perjanjian antara pekerja dengan pengusaha, dalam keadaan ini asas kebebasan berkontrak dan pacta sunt servanda (perjanjian yang dibuat sesuai dengan undang-undang berlaku/mengikat seperti undang-undang bagi para pihaknya (Sefriani, 2010) tidak terpenuhi sebagaimana perjanjian pada umumnya. Di dalam Pasal 1338 KUHPerdata, pacta sunt servanda diwujudkan dengan:

1. Semua persetujuan yang dibuat sesuai dengan undang-undang, berlaku sebagai undang-undang bagi mereka yang membuatnya;

2. Persetujuan itu tidak dapat ditarik kembali selain dengan kesepakatan kedua belah pihak, atau karena alasanalasan yang ditentukan oleh undangundang.

Hal tersebut sejalan dengan pendapat yang dikemukakan oleh Hakim Konstitusi, Prof. Dr. Aswanto, S.H., M.Si., DFM., pekerja menjadi pihak yang berada dalam posisi yang lebih lemah karena sebagai pihak yang membutuhkan pekerjaan. Dengan adanya posisi yang tidak seimbang tersebut, maka filosofi kebebasan berkontrak yang merupakan salah satu syarat sahnya perjanjian menjadi tidak sepenuhnya terpenuhi (Aswanto, n.d.).

Baik dalam perjanjian kerja bersama dan peraturan perusahaan, ketentuannya tidak boleh bertentangan dengan perundangundangan yang berlaku. Dalam hal isi perjanjian kerja bersama maupun aturan perusahaan bertentangan, maka ketentuan yang bertentangan tersebut batal demi hukum dan yang berlaku adalah ketentuan dalam peraturan perundang-undangan (Pasal 124 UU Ketenagakerjaan). Dengan demikian, peraturan perusahaan maupun perjanjian kerja bersama harus tunduk dan sesuai dengan peraturan perundangundangan yang berlaku, dalam hal ini UU Ketenagakerjaan. Begitupun seterusnya, undang-undang ketenagakerjaan tidak boleh bertentangan dengan muatan yang dikandung Undang-Undang Dasar Negara Republik Indonesia Tahun 1945.

\section{Simpulan}

1. Putusan Mahkamah Konstitusi Nomor: 13/PUU-XV/2017 memiliki kekuatan hukum tetap dan mengikat sehingga tidak ada lagi upaya hukum lain yang dapat ditempuh serta putusan mempunyai sifat final and binding, sehingga putusan Mahkamah Konstitusi tersebut tidak hanya berlaku bagi para pihak yang mengajukan Permohonan tetapi juga 
berlaku bagi seluruh masyarakat Indonesia.

2. Berlakunya Putusan Mahkamah Konstitusi tersebut, menimbulkan konsekuensi bahwa perusahaan tidak boleh melakukan pemutusan hubungan kerja kepada pegawainya yang memiliki ikatan perkawinan dengan pegawai lainnya dalam satu perusahaan, karena ketentuan Pasal 153 ayat 1 UU ketenagakerjaan tidak mempunyai kekuatan hukum mengikat.

3. Perusahaan yang masih menerapkan aturan larangan pernikahan sesama pegawai di perusahaan, baik di dalam peraturan perusahaan maupun perjanjian kerja bersama, harus melakukan penyesuaian agar terhindar dari timbulnya gugatan dari para pihak yang merasa dirugikan, karena ketentuan Pasal 153 ayat 1 UU Ketenagakerjaan bertentangan dengan UUD 1945 sebagai peraturan yang lebih tinggi tingkatannya, dengan demikian Pasal 153 ayat (1) UU Ketenagakerjaan yang djadikan dasar aturan internal perusahaan tidak mempunyai kekuatan hukum mengikat. Sehingga norma yang telah dinyatakan bertentangan dengan UUD 1945 tidak lagi dapat dijadikan dasar hukum untuk mengambil tindakan atau putusan

\section{DAFTAR PUSTAKA}

Aswanto. (n.d.). Sidang pleno Mahkamah Konstitusi pada tanggal 14 Desember 2017. Retrieved March 13, 2018, from http://www.mahkamahkonstitusi.go.id /index.php?page $=$ web. Berita $\& i d=1420$ 3\#.WqdWQ-hubIU

Daulay, I. (2006). Mahkamah Konstitusi Memahami Keberadaannya Dalam Sistem Ketatanegaraan Republik Indonesia. Jakarta: Rineka Cipta.

Isra, S. (2015). Titik Singgung Wewenang Mahkamah Agung dengan Mahkamah Konstitusi. Jurnal Hukum Dan Peradilan, 4(1), 17-30.

Kansil, C. (2004). Kitab Undang-Undang Hukum Ketenagakerjaan. Jakarta: Pradnya Paramita.

Kapitan, R. (2015). Kekuatan Mengikat Putusan Constitutional Review Mahkamah Konstitusi terhadap Mahkamah Agung. Masalah-Masalah Hukum, 44(4).

Maulidi, M. (2017). Problematika Hukum implementasi Putusan Final dan Mengikat Mahkamah Konstitusi Perspektif Negara Hukum. Jurnal Hukum Ius Quia Iutum, 24(4), 535557.

Novenanty, W. (2016). Pembatasan Hak Untuk Menikah Antara Pekerja Dalam Satu Perusahaan. Jurnal Veritas et 
Justitia, 2(1).

Prang, A. J. (2011). Implikasi Hukum Putusan Mahkamah Konstitusi. Kanun Jurnal Ilmu Hukum, 53(April), 77-94. Ratnaningsih, E. (2017). Asas Erga Omnes Dalam Putusan Mahkamah Konstitusi. Retrieved from http://businesslaw.binus.ac.id/2017/10/31/asas-ergaomnes-dalam-putusan-mahkamahkonstitusi/

Rusli, H. (2004). Hukum Ketenagakerjaan 2003. Jakarta: Ghalia Indonesia.

Samosir, D. (2015). Faktor-faktor yang
Menyebabkan Materi Muatan UU Bertentangan dengan UUD 1945. Jurnal Konstitusi, 12(4).

Sefriani. (2010). Hukum Internasional Suatu Pengantar. Jakarta: Raja Grafindo Persada.

Sutedi, A. (2009). Hukum Perburuhan. Jakarta: Sinar Grafika.

Thalib, A. (2006). Wewenang Mahkamah Konstitusi dan Implikasinya Dalam Sistem Ketatanegaraan Republik Indonesia. Bandung: Citra Aditya Bhakti. 